ROCZNIKI TEOLOGICZNE

Tom LXVII, zeszyt 5 - 2020

DOI: https://doi.org/10.18290/rt20675-4

LESZEK POLESZAK SCJ

\title{
DOŚWIADCZENIE CIERPIENIA JAKO PRÓBA NADZIEI I UFNOŚCI DO BOGA
}

\author{
EXPERIENCE OF SUFFERING AS A TRIAL \\ OF HOPE AND TRUST IN GOD
}

\begin{abstract}
Experience of pain and suffering is a border situation in one's life. Both for the believers and for the unbelievers it is a deep shock, which has its consequences in the life of a particular person as well as in their relationships with others. For the people who believe experience of suffering can become a trial of hope and trust in God. Adopting the right stance facing suffering allows the person to revalue its meaning and additionally to find the answers for the most fundamental questions which suffering raise. The source of hope and trust for Christians is the risen Christ, who accepting suffering through love, added redeeming value to it. Suffering lived with Christ enriches a human being and allows him / her to mirror the only begotten Son of God.
\end{abstract}

Key words: suffering; hope; trust; trial of suffering.

Doświadczenie cierpienia, które stanowi sytuację graniczną w życiu człowieka, jest jednocześnie poważną próbą nadziei i ufności do Boga. Pomimo popularnej dziś ,kultury witalnej”, ideologii „kultu ciała” i ,wiecznej młodości”, podsycanych prymitywnym hedonizmem, beztroską i ideami permisywizmu, każdy człowiek, bez względu na wyznawaną wiarę, status społeczny czy światopogląd, będzie musiał prędzej czy później zmierzyć się z pytaniami dotyczącymi doświadczonego cierpienia, choroby i śmierci. Pytania te bowiem są ściśle związane z codziennym życiem człowieka, z jego kruchością i delikatnością. Nie da się ich zepchnąć do strefy „tabu” bądź przemilczeć. Doświadczenie cierpienia i bólu jest bowiem nieodzowną składową ludzkiego bytu ${ }^{1}$.

Dr LeSZEK POLESZAK SCJ - sercanin, rektor Wyższego Seminarium Misyjnego Księży Sercanów w Stadnikach, członek Polskiego Stowarzyszenia Teologów Duchowości; adres do korespondencji: e-mail: lpoleszak@scj.pl; ORCID: https://orcid.org/0000-0001-5408-0809.

${ }^{1}$ Warto w tym miejscu przytoczyć znamienne słowa papieża Franciszka: „Natura ludzka, zraniona przez grzech, ma wpisaną w sobie rzeczywistość ograniczenia. Znamy zarzut, który zwłaszcza w dzisiejszych czasach jest stawiany wobec egzystencji naznaczonej poważnymi ograniczeniami 
Dla osoby wierzącej Bóg stanowi ostoję jej najgłębszych pragnień, które w ostatecznym rozrachunku zmierzają do osiągnięcia wiecznego zbawienia. Doznawanie bólu i cierpienia sprawia, że człowiek bardziej koncentruje się na rzeczywistości ziemskiej, próbując zmienić to, co jest ich źródłem. Prędzej czy później dochodzi jednak do wniosku, że cierpienie stanowi nieunikniony element ludzkiego życia, z którym musi się mierzyć na różnych jego etapach.

\section{NIEODZOWNOŚĆ CIERPIENIA WOBEC PRAGNIENIA SZCZĘŚCIA}

Człowiek został stworzony do szczęścia i nieśmiertelności. Pragnie rozwijać się i żyć pełnią życia. Doświadcza jednak cierpienia, które boleśnie uświadamia mu jego skończoność i zależność. Marzenia o długowieczności, wiecznej młodości, informacje o gwałtownym rozwoju medycyny i nauk pomocniczych mieszają się z lękiem przed chorobą i śmiercią. Kwestie życia, choroby i umierania, dotykające poszczególne osoby, traktowane są jako rzeczy przykre, niemal wstydliwe, rodzące mieszane uczucia, niekiedy wręcz zażenowanie czy odrazę. Choroba, cierpienie i śmierć wykraczają jednak poza ujmowaną jedynie zjawiskowo nieodwracalną destrukcję organizmu, ujawniając swe głębsze, metafizyczne doświadczenie religijne, które zmienia znaczenie cierpienia i umierania ${ }^{2}$.

fizycznymi. Uważa się, że osoba chora lub niepełnosprawna nie może być szczęśliwa, ponieważ nie jest w stanie zrealizować stylu życia narzuconego przez kulturę przyjemności i rozrywki. W czasach, gdy pewna troska o ciało stała się masowym mitem, a zatem interesem ekonomicznym, to co jest niedoskonałe, musi być przysłonięte, ponieważ wymierzone jest w szczęście i spokój ludzi uprzywilejowanych i ponieważ podważa model dominujący. Lepiej trzymać te osoby w separacji, w jakimś ogrodzeniu - może i złotym - czy też w «rezerwatach» litości czy pomocy społecznej, aby nie opóźniały rytmu fałszywego dobrobytu. W niektórych przypadkach uważa się wręcz, że lepiej jest pozbyć się ich jak najszybciej, ponieważ stają się one nieznośnym obciążeniem finansowym w czasach kryzysu. W istocie jednak jakąż iluzją żyje dzisiejszy człowiek, kiedy zamyka oczy w obliczu choroby i niepełnosprawności! Nie rozumie on prawdziwego sensu życia, które pociąga za sobą także akceptację cierpienia i ograniczeń. Świat nie staje się lepszy, ponieważ składa się wyłącznie z osób pozornie «doskonałych», żeby nie powiedzieć «ucharakteryzowanych», ale kiedy wzrasta solidarność między ludźmi, wzajemna akceptacja i szacunek. Jakże prawdziwe są słowa Apostoła: «Bóg wybrał właśnie to, co niemocne, aby mocnych poniżyć» (1 Kor 1,27)!". FRANCISZEK, Uśmiech jako lekarstwo. Homilia podczas Mszy św. z okazji Jubileuszu Osób Chorych i Niepetnosprawnych (12.06.2016 r.), https://opoka.org.pl/biblioteka/W/WP/franciszek_i/homilie/chorzy_12062016.html (dostęp: 23.07.2020r.). Por. P. MRZYGŁóD, Etyczno-moralne postawy wobec cierpienia, nieuleczalnej choroby i śmierci człowieka $-w$ świetle ustaleń antropologii filozoficznej, „Studia Teologiczne Białystok Drohiczyn Łomża” 34(2016), s. 61-65.

${ }^{2}$ Por. P. MrZYGŁóD, Filozoficzno-egzystencjalna anatomia choroby, cierpienia i śmierci, „Wrocławski Przegląd Teologiczny” 2(24) (2016), s. 73-75. 
Cierpienie definiowane jest jako stan psychiczny człowieka, który zostaje wywołany bólem fizycznym lub psychicznym. Źródłem tego bólu mogą być niedomagania organizmu ludzkiego spowodowane chorobą bądź też trudnością albo niemożnością zrealizowania zamierzonego celu, albo też przeżyciem napotkanej przykrości. Możemy więc mówić o cierpieniu fizycznym i psychicznym. Cierpienie stanowi nieodłączny komponent życia ludzkiego i jest związane z ograniczonością bytowej struktury człowieka. W rozważaniach na temat cierpienia często podkreśla się jego wartość oczyszczającą w odniesieniu nie tylko do życia przyrodzonego (katharsis), ale także do życia nadprzyrodzonego (pokuta) ${ }^{3}$.

Ludzkie cierpienie posiada zakres wielowymiarowy i znacznie szerszy od tego, co zostało odkryte i opisane przez biologię i medycynę. Człowiek zostaje nim dotknięty nie tylko jako podmiot fizycznego i egzystencjalnego bólu, ma ono także znaczący wpływ na całą jego aktywność i na relacje międzyludzkie. Cierpienie, będąc czymś bardziej podstawowym od choroby, jest „bardziej wielorakim, a zarazem głębiej jeszcze osadzonym w całym człowieczeństwie" ${ }^{\natural 4}$. Łączność, jaka zachodzi między sferą duchową i materialną w człowieku sprawia, że doświadczane cierpienie fizyczne ,zniewala ducha”, zaś cierpienie duchowe „ujarzmia” także ludzkie ciało. Jan Paweł II zauważa, że w doświadczeniu ludzkiego cierpienia mamy do czynienia z trudną do określenia coincidentia oppositorum (jednością i zbieżnością przeciwieństw) ${ }^{5}$.

Możliwość podlegania cierpieniu wynika z przygodnej, czyli stworzonej natury człowieka. Cierpienie jest jednak także związane z grzechem pierworodnym i jest jego skutkiem. „Dopóki odbywamy tę ziemską pielgrzymkę, dopóty istnieć będą cierpienie i choroba. Są one częścią kondycji człowieka i w rezultacie są wynikiem grzechu pierworodnego, lecz niekoniecznie są winą poszczególnej osoby. Wielu ludzi w różnym wieku cierpi bez żadnej własnej winy"6.

Nieodzowność cierpienia stawia pod znakiem zapytania możliwość osiągnięcia stanu szczęścia. Wprowadza człowieka w doświadczenie próby w jego relacji do siebie samego, do świata i do Stwórcy. Uświadamia ono przede wszystkim kruchość ludzkiej natury i nietrwałość ludzkich zamiarów. Także w relacji do innych

\footnotetext{
${ }^{3}$ Por. F. BuJAK, Cierpienie. Struktura psychiczna, w: Encyklopedia Katolicka, t. 3, Lublin 1995, k. 476.

${ }^{4}$ Por. Jan PaweŁ II, List apostolski Salvifici doloris, Rzym 1984 (dalej: SD), 5.

${ }^{5}$ Por. TENŻE, Medycyna na stużbie życia i człowieka. Przemówienie do uczestników XV Międzynarodowego Kongresu Federacji Stowarzyszeń Lekarzy Katolickich (3.10.1982 r.), OsRom 11-12(1982), s. 5-7. Por. także: P. MRZYGŁÓD, Filozoficzno-egzystencjalna anatomia choroby, cierpienia i śmierci, s. $80-81$.

${ }^{6}$ Jan Pawee II, W szpitalu św. Karola Boromeusza w Onitsha. Chrześcijański sens cierpienia i starości, w: TENŻE, Nauczanie papieskie, t. V, 1 (1982), Poznań 1993, s. 186.
} 
każe postawić fundamentalne pytania o to, czym jest ludzkie życie, czym jest szczęście, jaki jest kres człowieka i jego cel. Doświadczenie cierpienia ostatecznie każe postawić także pytanie dotyczące jego przyczyn i tego, jaka jest w nim rola Boga. I właśnie w tym punkcie najbardziej daje się zauważyć związek przeżywania nadziei chrześcijańskiej z wiarą i miłością, bez których doświadczenie cierpienia prowadzi człowieka do rozpaczy, bezradności i życiowej klęski, koncentrując się na tym, czego aktualnie się doświadcza i zamykając możliwość spojrzenia $\mathrm{w}$ przyszłość, poza aktualną sytuację. To natomiast niweluje możliwość spojrzenia wiary, w perspektywie nadziei i ufności, jaką przynosi Osoba Jezusa Chrystusa.

\section{DOŚWIADCZENIE CIERPIENIA JAKO PRÓBA NADZIEI I UFNOŚCI DO BOGA}

Nadzieja jest pragnieniem, poprzez które człowiek dąży do osiągnięcia przyszłego dobra. W nawiązaniu do ujęcia biblijnego nadziei, teologia określa ją jako oczekiwanie na urzeczywistnienie się obietnic Bożych. Jako cnota nadprzyrodzona wyrasta ona z wiary i wyraża się w miłości. Podstawowym i najważniejszym przedmiotem nadziei chrześcijanina jest spodziewanie się od Boga życia wiecznego, dzięki obietnicy zbawienia otrzymanej od Jezusa Chrystusa. Teksty starotestamentalne wskazują, że nadzieja rodzi się w sytuacji zagrożenia, nieszczęścia i niepewności. Człowiek zwraca się wówczas w kierunku przyszłości, która może przynieść wybawienie i ocalenie dzięki pomocy i opiece Boga: „Odpocznij jedynie w Bogu, duszo moja, bo od Niego pochodzi moja nadzieja. On jedynie opoką i zbawieniem moim, bo od Niego pochodzi moja nadzieja" (Ps 62,6-7; por. Ps 9,19; Lm 3,28-29). Prawdziwą nadzieję cechuje pokładanie ufności w Bogu, od którego człowiek bądź naród spodziewa się pomocy i wyzwolenia z doświadczanych opresji. Możemy odróżnić nadzieję prawdziwą, rzeczywistą, od nadziei płonnej, czyli fałszywej (por. Iz 40,28-31; Jr 17-5-8). Pan Bóg okazuje swoją pomoc wobec wierzących w sytuacjach granicznych, w samotności, nieszczęściu i cierpieniu, okazując swoją bliskość, uwalniając od wewnętrznych udręk, stając w obronie wierzącego. Szczególnym przykładem ingerencji Bożej wobec niezawinionego cierpienia jest sytuacja Hioba. Chociaż zostaje on dotknięty niezawinionym cierpieniem, ufa Bogu mając głębokie przeświadczenie, że towarzyszy mu Jego błogosławieństwo i łaska. Pomimo tragedii i cierpień, które go dotykają, trwa on w wielkiej ufności wobec Stwórcy, spodziewając się od Niego obrony. W Starym Testamencie jedynym celem nadziei, jej treścią i gwarantem 
jest sam Bóg, w którym zarówno poszczególny człowiek, jak i cały naród pokładają swoją ufność ${ }^{7}$.

W Nowym Testamencie nadzieja to oczekiwanie dobra oraz zbawienia, często wbrew różnorodnym przeciwnościom losu. Koncepcja nadziei nie oznacza więc osobistej postawy osoby wierzącej, lecz obiektywne dobro, którego człowiek się spodziewa. „Dzięki czynimy Bogu, Ojcu Pana naszego, Jezusa Chrystusa, zawsze, ilekroć modlimy się za was odkąd usłyszeliśmy o waszej wierze w Chrystusie Jezusie i o waszej miłości, jaką żywicie dla wszystkich świętych z powodu nadziei [nagrody] odłożonej dla was w niebie (1 Kol 1,3-5; por. Ga 5,5; Tt 2,13). Nadzieja wiąże się z oczekiwaniem, którego sens Jezus wyjaśnia w przypowieściach o nadejściu Królestwa Bożego. W nich człowiek odnajduje uzasadnienie dla bezwarunkowego pokładania nadziei w Bogu, który zawsze okazuje się wierny swoim obietnicom. Przypowieści te wskazują także na pewne napięcie pomiędzy tym, co ,już” się spełnia w przepowiadaniu i czynach Jezusa a rzeczywistością, która ,jeszcze nie” została objęta zbawieniem i wciąż znajduje się pod panowaniem grzechu i śmierci. Pewność chrześcijańskiej nadziei zostaje zakorzeniona w zmartwychwstaniu Syna Bożego. Jego ponowne przyjście sprawi, że wszystko zostanie ostatecznie Mu poddane i przeniknięte mocą Ducha Świętego ${ }^{8}$.

Każda postać cierpienia, jakiego człowiek doświadcza, stanowi w jakiś sposób wstrząs w normalnym życiu człowieka. W swoim przemówieniu do trędowatych w Marituba Jan Paweł II stwierdził, że jest ono próbą, która jednak zawiera w sobie zalążek pocieszenia: „Choroba naprawdę jest krzyżem, czasami ciężkim krzyżem, próbą, którą Bóg dopuszcza w życiu człowieka, w niepojętej tajemnicy planu, który wymyka się naszym zdolnościom pojmowania. Ale nie powinna ona być widziana jako ślepe przeznaczenie. Nie musi też być wcale sama w sobie karą. Nie jest czymś, co unicestwia, nie zostawiając nic pozytywnego. Przeciwnie, krzyż choroby, nawet kiedy ciąży ciału, niesiony w łączności z krzyżem Chrystusa staje się źródłem zbawienia, życia i zmartwychwstania, dla samego chorego i dla innych, dla całej ludzkości. [...] Pewien jestem, że choroba widziana w takim świetle, chociaż boleśnie i po ludzku umartwiająca, zawiera w sobie zalążek nadziei i niesie nowe pocieszenie" .

Cierpienie fizyczne, jak też psychiczne mają olbrzymi wpływ zarówno na życie społeczne człowieka, jak też na jego relację do Boga. Bunt i sprzeciw wobec

\footnotetext{
${ }^{7}$ Por. Z. PAWŁowsKI, Nadzieja. W Biblii, w: Encyklopedia Katolicka, t. 13, Lublin 2009, k. 635-636.

${ }^{8}$ Por. tamże, k. 636. Por. także: J. W. Gogola, Nadzieja. Aspekt duchowy, w: Encyklopedia Katolicka, t. 13, k. 638; B. J. HuculaK, Nadzieja. Aspekt teologiczny, w: Encyklopedia Katolicka, t. 13, k. 637-638.

${ }^{9}$ Jan Pawet II, Przemówienie do trędowatych w Marituba 8.07.1980 r., w: TENŻE, O cierpieniu. Wypowiedzi Ojca Świętego do chorych i pracowników stużby zdrowia (1978-1982), Warszawa 1985, s. 97.
} 
doświadczanego bólu przekłada się na odniesienie do siebie samego, rodziny, społeczeństwa. Cierpienie wpływa na życie duchowe człowieka oraz rozwój jego wiary i ufności do Boga. Niezwykle ważny w tym względzie jest sposób przeżywania cierpienia oraz postawa, jaką wobec niego przyjmuje. Wpływa ono na stany emocjonalne człowieka, może uczynić go aroganckim i nieznośnym dla otoczenia, może go złamać i „wyciszyć”, zamykając w pokornym przeżywaniu doświadczanego bólu i słabości. Każdy człowiek okazuje się niezmiernie wrażliwy na cierpienie, którego przychodzi mu doświadczać. Nawet osoby niewierzące, w sytuacji doznanego cierpienia, zaczynają stawiać sobie fundamentalne pytania o sens życia, wiarę, hierarchię wartości, a w ostateczności również pytania o własną relację do Boga, o wieczne szczęście i ostateczne „rozliczenie” swojego życia. Bez wątpienia cierpienie, a zwłaszcza choroba, niejednokrotnie stają się poważną próbą nadziei i ufności do Boga, także dla osób o głębokiej wierze ${ }^{10}$.

\section{POSTAWA WOBEC CIERPIENIA}

Dla właściwego przeżycia granicznej sytuacji doświadczenia cierpienia niezbędne jest przyjęcie właściwej postawy wobec niego. Może być to postawa obrony, buntu, tolerancji lub akceptacji. Przyjęta postawa zależna jest od tego, jak postrzegany jest sens i cel cierpienia. Obrona przed cierpieniem charakteryzuje się szukaniem środków mogących je oddalić lub przynajmniej uśmierzyć. Wynika ona z przekonania o jego bezsensowności i jest próbą samoobrony człowieka. Postawa buntu wyraża brak akceptacji cierpienia, zaciemnia władze wolitywne, które znajdują się wówczas pod silnym wpływem doznawanych emocji. Trudno jest wówczas odnaleźć sens cierpienia i dostrzec jego motywy. Postawa tolerancji jest oznaką pogodzenia się $\mathrm{z}$ nieuchronnością cierpienia przy jednoczesnym działaniu zmierzającym do uniewrażliwienia się na nie. Człowiek stara się wówczas opanować sferę emocjonalną. Ostatnią postawą wobec cierpienia jest akceptacja. Człowiek, zdając sobie sprawę z jego nieuchronności, przyjmuje je. W przypadku osób niewierzących motywem przewodnim może być tutaj realizm życiowy. Dla wierzących może być to powinność moralna postrzegająca cierpienie jako składnik ludzkiego życia z woli Bożej. Najdojrzalszym i najwyższym motywem przyjęcia cierpienia, który jednocześnie przyczynia się do jego przewartościowania, jest miłość. Akceptacja

\footnotetext{
${ }^{10}$ Por. A. OlCZYK, Postannictwo Kościoła wobec chorych, „Studia Gdańskie” 35 (2014), s. 78-79; P. MRZYGŁóD, Filozoficzno-egzystencjalna anatomia choroby, cierpienia i śmierci, s. 81-85.
} 
cierpienia powodowana miłością sprawia, że człowiek może dostrzec jego głębszy, religijny sens, który włącza doznawane cierpienie w przemieniającą perspektywę porządku łaski na wzór Jezusa Chrystusa. Najwyższą formą religijnej duchowości człowieka jest umiłowanie cierpienia (amor crucis). Motywem akceptacji cierpienia jest wówczas zbawienie bliźniego ${ }^{11}$.

Pewną pomoc w zrozumieniu relacji cierpienia do nadziei i zaufania Panu Bogu przynosi nam studium Edyty Stein ${ }^{12}$ Wiedza Krzyża ${ }^{13}$. „Krzyż” dla Edyty Stein jest pojęciem wspólnym opisującym wszystko to, co w sposób nieproszony pojawia się w życiu człowieka. Określa nim sytuację choroby, nędzy, cierpienia i udręki wszelkiego rodzaju. Krzyż oznacza więc takie cierpienie, które okazuje się nieprzezwyciężalne. Człowiek pozostaje wobec niego bezradny, pomimo że dokłada różnorakich starań, by się z nim uporać. Autorka podkreśla, że wielką umiejętnością jest przyjęcie tego cierpienia i zgoda na to, by kroczyć drogą naznaczoną krzyżem. Dla niej przyjęcie krzyża w perspektywie wiary i miłości do Boga nie ma nic wspólnego z cierpiętnictwem, masochizmem, szukaniem dodatkowego bólu czy biernym podleganiem temu, czego się doświadcza. Przyjęcie krzyża jest postawą godną człowieka wobec bólu, jakiego on doznaje. Krzyż oznacza więc jakąś formę cierpienia i stanowi znak reprezentatywny. Edyta Stein w krzyżu widzi podwójny symbol: jest on najpierw oznaką wszystkiego, co wiąże się z przytłaczającym cierpieniem i co prowadzi do śmierci, z drugiej zaś strony stanowi on symbol drogi do wiecznego życia. Przyjmując na siebie krzyż, człowiek zdobywa głęboką wiedzę krzyża i ostateczne zbawienie. Ten podwójny wymiar krzyża związany jest z faktem, że krzyż Chrystusa to nie tylko cierpienie i śmierć, ale także znak zmartwychwstania i odkupienia, jakie człowiek otrzymuje od swojego Zbawiciela Jezusa Chrystusa ${ }^{14}$.

Takie ujęcie cierpienia i krzyża wywodzi się z teologii świętego Pawła Apostoła (por. 1 Kor 1; Flp 2,7-8). Dla niego krzyż nie może być utożsamiany jedynie z męką i cierpieniem Chrystusa, jest on bowiem także narzędziem odkupienia świata, znakiem wskazującym na to, co stanowi cel ostateczny człowieka, którym jest zbawienie i życie wieczne. Krzyż dla św. Pawła jest również symbolem śmierci człowieka dla świata. Umierając dla grzechu, rodzi się on do życia według Ducha (por. Ga 2,19-20; Rz 6,3-4). Wiara w Chrystusa

\footnotetext{
${ }^{11}$ Por. S. WiteK, Cierpienie. Aspekt aksjologiczny, w: Encyklopedia Katolicka, t. 3, k. 480.

${ }^{12}$ Edyta Stein - św. Teresa Benedykta od Krzyża (1891-1942), niemiecka filozof i fenomenolog, karmelitanka bosa, męczennica Kościoła katolickiego oraz patronka Europy.

${ }^{13}$ Por. Teresa Benedykta od Krzyża (Edyta Stein), Wiedza Krzyża. Studium o św. Janie od Krzyża, Kraków 2005.

${ }^{14}$ Por. A. SzuLC, Edith Stein „philosophia crucis” jako wiedza cierpienia, „Rocznik Filozoficzny Ignatianum" 1(19) (2013), s. 36-37.
} 
ukrzyżowanego staje się początkiem przyszłej chwały, jaka czeka wytrwałych. Krzyż stanowi więc tytuł do chluby, jest głupstwem dla pogan, którzy nie rozumieją jego sensu ${ }^{15}$.

Przyjęcie godnej postawy wobec cierpienia powoduje wewnętrzny wzrost człowieka, ubogaca go i pozwala mu coraz bardziej dojrzewać. Możemy jednak zapytać, czy takie podejście do cierpienia jest ograniczone jedynie do osób, które wierzą w Boga? Według koncepcji homo patiens Viktora E. Frankla ${ }^{16}$ cierpienie powoduje niekiedy lęk przed wymiarem duchowym. Człowiek może się buntować przeciwko losowi, próbując walczyć z doświadczanym cierpieniem, a widząc, że jego zmagania nie przynoszą rezultatów, może nawet ulegać frustracji. Według uczonego właściwą postawą w takiej sytuacji granicznej jest akceptacja własnego losu, pogodzenie się z tym, co nieuniknione i nadanie mu sensu. W ten sposób człowiek akceptuje cierpienie, nadaje mu sens i transcenduje je $\mathrm{j}^{17}$. Doświadczając przeciwności i cierpienia człowiek konfrontuje swoją hierarchię wartości, która ulega zaburzeniu. Cierpienie nie jest jednak konieczne do tego, by odkryć jego sens, a także sens własnego życia.

Porównując rozważania Edyty Stein z badaniami nad cierpieniem Viktora E. Frankla można dojść do wniosku, że nadanie cierpieniu sensu jest kluczowym momentem w sytuacji granicznej człowieka. Wyrywając go z jego codzienności, doświadczenie bólu i cierpienia skłania go do zwrócenia się do swojego wnętrza, co może stać się warunkiem rozwoju tożsamości i człowieczeństwa. Zarówno człowiek wierzący, jak też niewierzący, który poszukuje prawdy, ostatecznie zgodnie z intuicją św. Teresy Benedykty od Krzyża - poszukuje Boga. Przyjmując natomiast właściwą (godną) postawę wobec cierpienia, żyje według wiedzy krzyża, chociaż nie zawsze sobie to uświadamia. Przyjęcie cierpienia i nadanie mu sensu poprzez ofiarowanie go, czyni człowieka współuczestnikiem w cierpieniu i ofierze Jezusa Chrystusa. W ten sposób otwiera się on na nową nadzieję i ufność, która pochodzi od samego Boga ${ }^{18}$.

O akceptacji cierpienia i jego skutkach mówił często do chorych św. Jan Paweł II. W jednym z przemówień zwrócił on uwagę, że przyjęcie cierpienia, bez pomniejszania go lub wyolbrzymiania sprawia, że w chorym odradza się pogoda ducha i nadzieja. „Jakiekolwiek jest wasze cierpienie, fizyczne czy

\footnotetext{
${ }^{15}$ Por. Teresa Benedykta od Krzyża (Edyta Stein), Wiedza Krzyża, s. 60-63. Por. także: A. SzULC, Edith Stein „philosophia crucis” jako wiedza cierpienia, s. 38.

${ }^{16}$ Viktor E. FRANKL (1905-1997) - austriacki psychiatra i psychoterapeuta, neurolog, filozof, twórca logoterapii.

${ }^{17}$ Por. V.E. FrAnkL, Homo patiens: Homo patiens. Logoterapia i jej kliniczne zastosowanie. Pluralizm nauk a jedność człowieka. Człowiek wolny, Warszawa 1998.

${ }^{18}$ Por. A. SzulC, Edith Stein „philosophia crucis” jako wiedza cierpienia, s. 43-46.
} 
moralne, osobiste czy rodzinne, apostolskie, czyli kościelne, ważne jest, abyście je sobie jasno bez pomniejszania go ani wyolbrzymiania, uświadomili wraz z całym łańcuszkiem reakcji, jakie rodzi ono w waszej ludzkiej wrażliwości: poczuciem klęski, bezużyteczności własnego życia. Następnie jest rzeczą konieczną, by postępować na drodze akceptacji. Tak, akceptować ten stan rzeczy, nie na zasadzie mniej lub bardziej ślepej rezygnacji, ale dlatego, że wiara zapewnia nas, iż Pan może i pragnie wyprowadzić dobro ze zła. Jakże wielu z was mogłoby zaświadczyć, że cierpienie, zaakceptowane w wierze, odradza pogodę ducha, nadzieję. I wreszcie najpiękniejszy gest, który możecie uczynić: ofiara. Dar złożony z miłości do Pana i do naszych braci pozwala osiągnąć, nieraz w stopniu bardzo wysokim, teologiczną cnotę miłości, to znaczy zatracenie się w miłości Chrystusa i Przenajświętszej Trójcy do ludzkości. Te trzy etapy przeżyte przez każdego, kto cierpi, wedle jego własnego rytmu i otrzymanej łaski, przyniosą zdumiewającą wolność wewnętrzną"19.

Próba wiary i ufności wobec Boga, jaką jest sytuacja cierpienia, zostaje przezwyciężona przez to, że posiada ono wartość odkupieńczą. Odkupieńcza wartość cierpienia wynika $\mathrm{z}$ faktu wejścia $\mathrm{w}$ tę trudną egzystencjalną przestrzeń Boga w akcie wcielenia. Odtąd może być ono również miejscem spotkania z Bogiem. Cierpienie dzięki wcieleniu Syna Bożego przestaje być przestrzenią obcą Bogu. Co więcej, wiąże się ono z miłością i ma moc wyzwalania miłości, która nadaje mu nowy sens. Jan Paweł II w liście apostolskim Salvifici doloris wyjaśnia to następująco: „Odkupiciel cierpiał za człowieka - i dla człowieka. Każdy człowiek ma udziat w Odkupieniu. Każdy też jest wezwany do uczestnictwa w owym cierpieniu, przez które Odkupienie się dokonało. Jest wezwany do uczestnictwa w tym cierpieniu, przez które każde ludzkie cierpienie zostało także odkupione. Dokonując Odkupienia przez cierpienie, Chrystus wynióst zarazem ludzkie cierpienie na poziom Odkupienia. Przeto też w swoim ludzkim cierpieniu każdy człowiek może stać się uczestnikiem odkupieńczego cierpienia Chrystusa"20. Przeżywając swoje cierpienie w zjednoczeniu z cierpiącym Chrystusem człowiek przekracza cierpienie i śmierć w kierunku życia wiecznego. Chociaż cierpienie samo w sobie nie posiada waloru soteriologicznego, jednak współistnienie miłości wraz z cierpieniem wyzwala taki element. To miłość sprawia, że poprzez cierpienie człowiek może przybliżyć się do Boga ${ }^{21}$.

\footnotetext{
${ }^{19}$ JAN PAWEE II, Przemówienie do chorych Cierpienie świadome, przyjęte z wiara $i$ ofiarowane czyni nas wspótpracownikami Chrystusa 15.08 .1983 r., w: Dzieta zebrane, t. 10. Homilie i przemówienia z pielgrzymek. Europa, cz. 2, red. P. Ptasznik, Kraków 2008, s. 137.

${ }^{20}$ SD 19.

${ }^{21}$ Por. J. P. STRUMIŁOWSKI, Epifanijne znaczenie konania Jezusa w Ogrójcu w świetle „communicatio idiomatum”, „Polonia Sacra” 2(21)(2017), s. 189. Por. także: J. ZABIELSKI, Eschatologiczny wymiar ludzkiego cierpienia i śmierci, ,,Rocznik Teologii Katolickiej” 2(12) (2013), s. 223-227.
} 
Fundamentalne pytania człowieka, jakie rodzą się w sytuacjach doświadczonego cierpienia, domagają się odpowiedzi. Ma on prawo do tego, by jego nadzieja nie została zawiedziona. Nadzieja ta może się zrealizować jedynie w relacji do wiary i ufności, którą pokłada w Bogu. Tylko moc zbawcza, którą może otrzymać jedynie za pośrednictwem Jezusa Chrystusa, przynosi człowiekowi odpowiedź na najbardziej fundamentalne pytania o sens i wartość cierpienia, o sens życia, o przyszłość i o nadzieję zbawienia. „Przez swoją śmierć Jezus rzuca światło na sens życia i śmierci każdej istoty ludzkiej. Przed śmiercią modli się do Ojca o przebaczenie dla swoich prześladowców (por. Łk 23,34), zaś łotrowi, który prosi Go, by pamiętał o nim w swoim królestwie, odpowiada: «Zaprawdę, powiadam ci: Dziś ze Mną będziesz w raju» (Łk 23,43)"22. Paschalne dzieło Syna Bożego jest gwarancją, że nadzieja i ufność człowieka nie zostaną zawiedzione. „On zaś umarł za nas, gdyśmy jeszcze byli grzesznikami (por. Rz 5,8). Tym samym obwieszcza On, że życie osiąga swój szczyt, swój sens i swoją pełnię, kiedy zostaje złożone w darze" ${ }^{, 23}$.

Nadzieja chrześcijańska jest ściśle związana z ufnością wobec Boga. Podstawą zaufania Bogu jest jednak orędzie zmartwychwstania, fakt, że Jezus powstał z martwych i zasiada w chwale po prawicy Ojca. Prawda o wcieleniu i zmartwychwstaniu Chrystusa nadaje ludzkiej rzeczywistości, także sytuacjom granicznym, nowy sens i znaczenie. Człowiek może przemieniać cierpienie dzięki ufności i nadziei pokładanej w Bogu, który w Chrystusie Jezusie pokonał śmierć i przynosi mu nowe życie. Ta nadzieja sprawia, że cierpienie nie kojarzy się już jedynie z beznadziejną sytuacją, której nie da się pokonać, ale dzięki miłości i ufności Bogu nabiera nowego sensu i znaczenia, które owocują na życie przyszłe. „Wcielenie Syna Bożego oraz zbawienie, jakiego dokonał przez swoją śmierć i zmartwychwstanie, są zatem właściwym kryterium oceny rzeczywistości doczesnej i wszelkich zamysłów, które mają zapewnić człowiekowi życie coraz bardziej ludzkie" 24 .

Chrześcijańska nadzieja nie jest pasywnym oczekiwaniem lepszego życia. Polega ona na aktywnym życiu wiarą, która przepełniona jest świadomością, że jedynie przez krzyż możemy dotrzeć do radości zmartwychwstania. Osoba wierząca pragnie upodabniać się do Chrystusa, który w posłuszeństwie Ojcu

\footnotetext{
${ }^{22}$ JAN PAWEŁ II, Encyklika Evangelium vitae, Rzym 1995 (dalej: EV), 50.

${ }^{23}$ EV 51.

${ }^{24}$ JAN PAWEŁ II, Bulla ogłaszająca Wielki Jubileusz Roku 2000 Incarnationis mysterium, Rzym 1999, 1.
} 
pełnił Jego wolę. Realizacja takiej postawy jest możliwa tylko wtedy, kiedy człowiek otwiera się na działanie Ducha Świętego. Jego życie, przepełnione radością pomimo doświadczonych trudności, staje się dla innych świadectwem życia w zawierzeniu Bogu. Duch Święty chroni człowieka przed złudzeniami oraz kieruje go ku autentycznemu celowi życia i sprawia, że człowiek zostaje wyzwolony z pesymizmu i z nihilizmu ${ }^{25}$.

Zmartwychwstały Chrystus jest więc źródłem chrześcijańskiej nadziei i ufności. On jest gwarantem, że człowiek może w pełni rozwijać się nawet wtedy, gdy doświadcza trudności i cierpienia. Co więcej, cierpienie przeżywane wraz z Chrystusem w duchu chrześcijańskiej nadziei i ufności ubogaca człowieka i pozwala mu się rozwijać, upodabniając go coraz bardziej do obrazu Jednorodzonego Syna Bożego $^{26}$.

\section{BIBLIOGRAFIA}

BujaK F., Cierpienie. Struktura psychiczna, w: Encyklopedia Katolicka, t. 3, Lublin 1995, k. 476-477. DziUba A.F., Jezus Chrystus, nasza nadzieja, ,Studia Theologica Varsaviensia” 2(2017), s. 119-146.

FRANCISZEK, Uśmiech jako lekarstwo. Homilia podczas Mszy św. z okazji Jubileuszu Osób Chorych i Niepetnosprawnych (12.06.2016 r.), https://opoka.org.pl/biblioteka/W/WP/franciszek_i/homilie/ chorzy_12062016.html (dostęp: 23.07.2020 r.).

Frankl V. E., Homo patiens: Homo patiens. Logoterapia i jej kliniczne zastosowanie. Pluralizm nauk a jedność człowieka. Człowiek wolny, Warszawa 1998.

GoGola J.W., Nadzieja. Aspekt duchowy, w: Encyklopedia Katolicka, t. 13, Lublin 2009, k. 638-639.

HuCUlaK B.J., Nadzieja. Aspekt teologiczny, w: Encyklopedia Katolicka, t. 13, Lublin 2009, k. 637-638.

JAN PAWEe II, Audiencja środowa 18.04.1979 r., w: TENŻE, O cierpieniu. Wypowiedzi Ojca Świętego do chorych i pracowników stużby zdrowia (1978-1982), Warszawa 1985, s. 30.

JAN PAWEe II, Bulla ogłaszająca Wielki Jubileusz Roku 2000 Incarnationis mysterium, Rzym 1999.

JAN PAWEe II, Duch Święty zadatkiem eschatologicznej nadziei i sprawca wytrwania aż do końca, w: Dzieta zebrane, t. 7. Katechezy, cz. 2, red. P. Ptasznik, Kraków 2007, s. 321-323.

JAN PAWEe II, Encyklika Evangelium vitae, Rzym 1995.

JAN PAWE€ II, List apostolski Salvifici doloris, Rzym 1984.

\footnotetext{
${ }^{25}$ Por. TENŻE, Duch Święty zadatkiem eschatologicznej nadziei $i$ sprawca wytrwania aż do końca, w: Dzieła zebrane, t. 7. Katechezy, cz. 2, red. P. Ptasznik Kraków 2007, s. 321. Por. także: A.F. DziuBA, Jezus Chrystus, nasza nadzieja, „Studia Theologica Varsaviensia” 2(2017), s. 136-139.

${ }^{26}$ Zmartwychwstały Chrystus nadaje cierpieniu nową godność. ,Per crucem ad lucem, to jest: poprzez cierpienia Krzyża osiąga się błogosławieństwo światła. Chrystus swoim zmartwychwstaniem odkupił, wybawił ból, który przez to zyskał swoją godność, bo został pozbawiony swojej bezużyteczności, by stać się pozytywnym źródłem dobra i świetlanym znakiem nadziei, która nie zawiedzie”. JAN PAWEe II, Audiencja środowa 18.04.1979 r., w: TENŻE, O cierpieniu.., s. 30.
} 
JAN PAwet II, Medycyna na stużbie życia i człowieka. Przemówienie do uczestników XV Międzynarodowego Kongresu Federacji Stowarzyszeń Lekarzy Katolickich (3.10.1982 r.), OsRom 11-12 (1982), s. 5-7.

Jan Pawet II, Przemówienie do chorych Cierpienie świadome, przyjęte z wiara $i$ ofiarowane czyni nas wspótpracownikami Chrystusa 15.08 .1983 r., w: Dzieta zebrane, t. 10. Homilie i przemówienia z pielgrzymek. Europa, cz. 2, red. P. Ptasznik, Kraków 2008, s. 135-137.

JAN PAwEŁ II, Przemówienie do trędowatych w Marituba, w: TENŻE, O cierpieniu. Wypowiedzi Ojca Świętego do chorych i pracowników stużby zdrowia (1978-1982), Warszawa 1985, s. 95-99.

JAN PAWEe II, W szpitalu św. Karola Boromeusza w Onitsha. Chrześcijański sens cierpienia i starości, w: TENŻE, Nauczanie papieskie, t. V, 1(1982), Poznań 1993, s. 186-187.

MRZYGŁóD P., Etyczno-moralne postawy wobec cierpienia, nieuleczalnej choroby i śmierci człowieka $-w$ świetle ustaleń antropologii filozoficznej, „Studia Teologiczne Białystok Drohiczyn Łomża” 34(2016), s. 61-92.

MrZYGŁóD P., Filozoficzno-egzystencjalna anatomia choroby, cierpienia i śmierci, „Wrocławski Przegląd Teologiczny” 2(24) (2016), s. 73-104.

Olczyк A., Postannictwo Kościoła wobec chorych, „Studia Gdańskie” 35(2014), s. 77-92.

PawŁowski Z., Nadzieja. W Biblii, w: Encyklopedia Katolicka, t. 13, Lublin 2009, k. 635-637.

STRUMiŁowski J.P., Epifanijne znaczenie konania Jezusa w Ogrójcu w świetle „communicatio idiomatum”, „Polonia Sacra” 2(21) (2017), s. 185-203.

SzULC A., Edith Stein „philosophia crucis” jako wiedza cierpienia, „Rocznik Filozoficzny Ignatianum" 1(19) (2013), s. 34-49.

Teresa Benedykta od Krzyża (Edyta Stein), Wiedza Krzyża. Studium o św. Janie od Krzyża, Kraków 2005.

WITEK S., Cierpienie. Aspekt aksjologiczny, w: Encyklopedia Katolicka, t. 3, Lublin 1995, k. 480-481.

ZABIELSKI J., Eschatologiczny wymiar ludzkiego cierpienia i śmierci, „Rocznik Teologii Katolickiej” 2(12) (2013), s. 219-230.

\section{DOŚWIADCZENIE CIERPIENIA \\ JAKO PRÓBA NADZIEI I UFNOŚCI DO BOGA}

\section{STRESZCZENIE}

Doświadczenie bólu i cierpienia stanowi sytuację graniczną w życiu człowieka. Dla wierzących, jak i niewierzących jest ono głębokim wstrząsem, mającym swoje skutki zarówno w życiu osobistym poszczególnych ludzi, jak też w ich relacjach do drugich. Dla osób wierzących doświadczenie cierpienia stanowi próbę nadziei i ufności do Boga. Przyjęcie właściwej postawy wobec cierpienia pozwala człowiekowi przewartościować je i znaleźć odpowiedź na najbardziej fundamentalne pytania, które zostają wywołane przez cierpienie. Źródłem nadziei i ufności dla chrześcijan jest zmartwychwstały Chrystus, który przyjmując cierpienie, dzięki miłości nadał mu wartość odkupieńczą. Cierpienie przeżywane z Chrystusem ubogaca człowieka i pozwala mu upodobnić się do Jednorodzonego Syna Bożego.

Słowa kluczowe: cierpienie; nadzieja; ufność; próba cierpienia. 